\title{
Kill the Corporation Before it Kills Life Itself: A Review of Reviews
}

\section{David Whyte ${ }^{1}$}

Published online: 18 December 2021

(c) The Author(s), under exclusive licence to Springer Nature B.V. 2021

There are lots of reasons that we read book reviews. We cannot read every book, so we need to know where to spend the time and effort. There is an element of sorting-or curation-that we get from book reviews. Where does the book fit in the literature? What is it saying that is different from other books? For people who write on the same topic, the point about reviews is to know what is going on elsewhere. How does this book connect with your own work? How is it distinguishable from your own work? But reading reviews of your own book is a daunting prospect. It is hard to even begin to read them. They can go either way. If we are honest, vanity is the main reason authors eventually get around to reading reviews of their own work. Yet, perhaps the most important function of book reviews is not "curation" or "vanity," it is that they represent the antithesis in the Hegelian dialectic. Book reviews are a good way to develop the critical, dissenting and opposing positions that allow us to reach a synthesis of ideas. If the arguments set out in books are not discussed and reflected on, they remain in a kind of paralysis, fixed in the time they were written. Book reviews allow the ideas and arguments contained within the book to be discarded or picked up in a different form; they allow the book to move on, or move aside, for the next set of ideas and arguments. I will try to move my book on-to bring it out of its fixed state-by surveying and responding to the criticisms set forth in the five reviews in this issue.

It is a huge honor to me that Critical Criminology: An International Journal commissioned the reviews of my book, Ecocide: Kill the Corporation Before It Kills Us (2020). In fact, it is a huge honor that five of my colleagues, who are all doing vital work in this area, have actually read it. The idea of this multiple review format was originally proposed as a virtual "author-meets-critics" forum. As Avi Brisman, the Editor-in-Chief of this journal said, if not for COVID 19, we would be meeting and debating things like this face-to-face. Having this discussion on those pages is, for me, a very special second best.

I am really grateful to the reviewers for their generosity and collegiality, and for their time and labor. These things take up a lot of our time, something that is not easy to find in the neoliberal university. And reviewing books for academic journals constitutes a type of labor that the neoliberal university does not value one iota. I have a colleague at the University of Liverpool who was told by his Head of Department to stop writing book reviews because they do not count in the Research Excellence Framework or "REF," as

David Whyte

David.Whyte@liverpool.ac.uk

1 University of Liverpool, Liverpool, UK 
it is known - the league table system for universities in the United Kingdom. His heroic response was to do nothing else other than to write book reviews.

Especially because this type work is not yet fully commodified, I am indebted to the reviewers, no matter how kind or critical they have been. And each of the reviews do contain praise, but they also contain either explicit or implicit criticisms. In the spirit of Hegelian dialectics, I will try, in this response, to deepen and, at times, exaggerate those critical points in order to emphasize the weaknesses and gaps in the book and to try to move the arguments and ideas forward.

Marília de Nardin Budó's review (2021) certainly identifies a major gap in my analysis. She notes that the discussion of the role of corporations and capitalism in processes of nature-destroying colonization lacks an understanding of both androcentrism and anthropocentrism. The corporation is a product of Western rational thinking that can conceptualize nature only in commodified terms, and the book maps this point out. But what is missing is a deeper critical engagement with rational thinking that exposes systematic patriarchy and speciesism. She is right: those perspectives are missing, and the analysis is weaker for it. The role of caring, social reproduction, subsistence production-in short, the reproduction of life-is critical to the story of the devouring of nature by Western corporations. Indeed, just as social reproduction is hidden in masculinist anthropogenic accounts, so is the leading role of women in peasant and Indigenous resistance movements across the planet (Barca 2020). To argue that colonialism was and remains the key driver in capitalism's unrestrained devouring of nature is to imply that all systems of human organization and of reproducing life were eradicated in its wake. The book only scratches the surface of this. But by accepting this approach, we also must agree that the ontological separation of humans from nature is a founding myth upon which early modernity's scientific revolution was based (Moore 2015). We must overcome this ontology if we are to have any chance of breaking the endless cycle of environmental destruction in capitalist social orders.

Similarly, Teresa Fajardo (2021: 2) sharply points out that "the author's approach to corporate ecocide is plainly anthropogenic." In her formulation, though, I do not see this as a criticism of my position; it is just a bold reflection on what it means to study corporations. Corporations are apparatuses of human creation and human organization. In so far as they involve humans organizing human activity then, yes, corporate ecocide is a plainly an anthropogenic problem. The history I point to is a human history and I blame the current climate crisis on human agency. Not any old human agency, but the emergence of European mercantilism based on colonialism and racial capitalism (Banaji 2021). In so far as the history of the European nation state and the Christian church does not feature centrally in the book's analysis, Fajardo is absolutely right. This is an incomplete anthropogenic approach, and thus would be a crucial addendum to understanding the history of corporate ecocide.

Fajardo also laments the omission of a human rights paradigm and the failure to see the United Nations (UN) as a potential solution. I get the point. We need to find solutions in all of the "loaded guns" (Fajardo 2021: 1) — the legal weaponry where struggles might find leverage over power. But, as a rule (one might say, "as a rule of law"), human rights will not save us. Neither will the UN. I am influenced, here, by my own empirical studies with my colleague Stefanie (Khoury and Whyte 2017, 2021), but also by the outcome of the 26th UN Climate Change Conference of the Parties (COP26) in Glasgow, Scotland, which is coming to a close as I write this. Despite the Intergovernmental Panel on Climate Change (IPCC) Report published before the conference (IPCC 2021) reasserting the need for outcomes that tie the big carbon producers to measures that can keep the world to a $1.5^{\circ} \mathrm{C}$ rise by 2100 - and despite the International Energy Agency (IEA) stressing the 
need to abandon all exploration and all new fossil fuel projects (IEA 2021) — COP26 got nowhere near the measures needed to achieve this. Instead, the best estimates predict that we are heading for a catastrophic rise of $2.4^{\circ} \mathrm{C}$ by 2100 (and this is even if we manage to meet all of the Glasgow targets). Glasgow did little more than consolidate a market definition of "zero" carbon that will keep fossil fuels being produced well beyond 2050 (Whyte 2021). This is the UN.

This is not to say that we cannot organize around and support legal initiatives. We are critical criminologists and our instinct is to look at the crimes of the powerful, identify the hypocrisy, and argue for a reversal in the logic of law. Our impulse is often to call for tougher penalties for corporate criminals. There is no shortage of studies and articles and books in which I, together with colleagues, including Anne Alvesalo, Steven Bittle, Andrew Moretta, Frank Pearce, Laureen Snider and Steve Tombs, have argued for criminalization of the powerful. Yet, we have never argued that criminalization could ever be the solution to corporate crime. When it comes to proposals for a new law of ecocide, it is clear that the doctrinal and political odds are stacked against such an offense being adopted and implemented with the intensity that could make even the slightest ripple in the balance of social forces. At the same time, we should not oppose such proposals as out of hand. Law is always a site of struggle, and the utility of each struggle depends on weighing the likely long-term gains (not just measured in legal terms, but also measured in terms of enhancing the prospects for building a movement). We just need to be realistic about the prospect of legal struggles for saving the planet.

On this measure, a more productive legal strategy may be to work toward an international treaty that ends fossil fuel production now (fossillfueltreaty.org 2021). A project like this, however, is likely to be more productive only if there is some prospect for organizing effective struggle around such demands and if such struggles can alter the balance of social forces. Ecocide: Kill the Corporation Before It Kills Us (2020) argues that whatever regulatory solution we fight for, we will always need to get to the heart of the problem. And at the heart of the problem lies the capitalist corporation. Reading these reviews has convinced me even more of the need to remove the corporation - the immortal embodiment of capital—from all climate-dependent economic activity.

For Avi Brisman (2021), a major reason to read is to affirm/confirm things that we already know, or think we know. We read to have our own views validated or reassured. No matter how much we seek to inquire about something we do not fully understand, perhaps this is also a major reason for writing. Or, citing Ray Michalowski's (1996) invocation to reach a useful truth through hearing and telling multiple versions of the same story, Brisman (2021) argues we need to hear tragedies told again and again from different perspectives. I am not sure I am comfortable with this. At COP26, repetitions of the same story-climate change and its remedies-are told and retold, and there is common ground between the stories told by the government and corporate leaders inside the cordon sanitaire at Glasgow and the protestors outside. They all tell variations of the story that we need system change and not climate change. We all know that unless our economic system changes radically, it will overheat the planet and probably lead to extinction of our species and countless other species. Capitalism's historical dependence on fossil fuels needs to be broken (Malm 2016). This is something that is universally agreed. The phrase, "system change, not climate change," becomes rather empty phrase, however, if we cannot specify what needs to be done. The first aim of the book is to bring us to a more concrete understanding of what system change might actually mean. And so, the book argues that "the corporation - the mechanism that capital uses to reproduce itself-was designed in a way that virtually guarantees ecocide. Understanding the capitalist corporation and then doing 
something about it must therefore be at the centre of the struggle to control climate change and the ecological crisis" (Whyte 2020: 4).

When we say we need to end capitalism, we need to specify what we mean by this. As Rob White (2021) argues in his review, this means nothing short of the abolition of private property and full socialization of the corporate enterprise. Only then can we hope for de-commodification of all the elements upon which human life depends. White's position is, for my money, inarguable. Indeed, as a formulation, it goes beyond simply killing the corporation. Yet we have to specify the institutional/constitutional form that capital and private property takes. Ecocide: Kill the Corporation Before It Kills Us (2020) does this in order to show how the social relationships that shape the corporation, and are embodied in the corporation, must be dismantled. As critical criminologists and legal scholars, we also have a responsibility to specify how law upholds the social relations of power upon which capitalism is based. And a major part of this task is to describe, in brutally honest terms, the prospects for dismantling the system. To map out the institutional detail of what must be disarmed and dismantled is to quite simply demonstrate that any social revolution that allows us to seriously and effectively confront the industrial and political conditions of climate change will not be quick or uncomplicated. The corporation will not simply wither seamlessly in the wake of an uprising of social movements.

This is a crucial theme picked up by Samuels-Jones' (2021). Here, she points out that none of the changes the book articulates will come about easily. She is absolutely right. It is all very well to argue that we must get rid of the corporation-and to formulate proposals to achieve this (e.g., to break up the corporate structure; to end impunity for shareholders; to end impunity for directors). But how do we get there? This is a struggle that will not be won by academic argument, but by confronting power on the streets, in communities and in workplaces. And there is little doubt that a meaningful attack on the corporation as an institution, including all of the privileges and protections granted to senior manager and shareholders, would require a social struggle on a scale and intensity that is, as yet, unprecedented.

To argue that the level of social power needed to change the system is a huge task does not mean that smaller struggles are pointless or that they cannot have some impact on the balance of social forces. Struggling for climate justice is not a zero-sum game. The book uses a case study of one corporation-the Finnish-Swedish firm Stora Enso-as a point of departure in each chapter. In Chapter 2, which looks at the colonialism and neocolonial function of the corporation, the discussion turns to Stora Enso's huge land holdings in Uruguay and Brazil. De Nardin Budó's writing has previously shown how a struggle by the Brazilian Landless Workers' Movement (Movimento dos Trabalhadores Sem Terra or the "MST") in Rio Grande du Sol was successful in removing Stora Enso from the state. This is significant. Transnational capital can be defeated and is defeated regularly. Indeed, the cumulative effect of local struggles can be very substantial indeed. One recent analysis shows that Indigenous struggles in North America have stopped or delayed greenhouse gas pollution that is equivalent to a quarter of the emissions from Canada and the United States (Goldtooth and Saldamando 2021). So while we need to secure a final victory against all corporations that profit from pollution and environment degradation-and this means nothing short of ending the system of universal commodification and profit accumulation-the struggle against individual capitals in the form of specific corporations and specific groups of investors is crucial for the planet.

The reviews published here have taught me that taking this path also means adopting an even broader conceptualization of the problem. The process of European colonization to which the book devotes a chapter is implicated in a deeper process of expropriation and denial of life than the book currently accounts for. The task of uncovering this process 
must incorporate struggles around social reproduction, work and everyday life, and must take seriously the idea that human life forms cannot be held as ontologically separate from all planetary life. When we incorporate a deeper analysis, in which corporations deny the possibility for social reproduction, and for all human and non-human forms of life to flourish, then "kill the corporation before it kills life itself" might be a more apt title for the next edition. That is, if we have not managed to kill the corporation before then.

\section{References}

Banaji, J. (2021). A Brief History of Commercial Capitalism. Chicago, IL: Haymarket.

Barca, S. (2020). Forces of Reproduction. Cambridge, UK: Cambridge University Press.

Budó, M. de Nardin. (2021). David Whyte: Ecocide: Kill the Corporation Before It Kills Us. Critical Criminology: International Journal, 29(4). https://doi.org/10.1007/s10612-021-09572-2.

Brisman, A. (2021). David Whyte: Ecocide-Kill the Corporation Before It Kills Us. Critical Criminology:International Journal, 29(4). https://doi.org/10.1007/s10612-021-09583-z.

Fajardo, T. (2021). David Whyte: Ecocide: Kill the Corporation Before It Kills Us. Critical Criminology: An International Journal, 29(4). https://doi.org/10.1007/s10612-021-09566-0.

Fossilfueltreaty.org. (2021). Fossil Fuel Non-Proliferation Treaty: Briefing Note: Aligning Fossil Fuel Production with $1.5^{\circ} \mathrm{C}$ and the Paris Agreement. Retrieved on November 12, 2021, from https://static1. squarespace.com/static/5dd3cc5b7fd99372fbb04561/t/6178bd5389fa492c37894a11/1635302740331/ Briefing+-\%C2\%A0Fossil+Fuel+Non-Proliferation+Treaty.pdf.

Goldtooth, D., \& Saldamando, A. (2021). Indigenous Resistance Against Carbon. Washington, DC: Oil Change International.

Intergovernmental Panel of Climate Change IPCC (2021). Climate Change 2021: The Physical Science Basis, the Working Group I contribution to the Sixth Assessment Report. Geneva: IPCC.

International Energy Agency (IEA). (2021). Net Zero by 2050: A Roadmap for the Global Energy Sector. Paris: International Energy Agency.

Khoury, S., \& Whyte, D. (2017). Corporate Human Rights Violations: Global Prospects for Legal Action. Abingdon, Oxon, UK, and New York: Routledge.

Khoury, S., \& Whyte, D. (2021). Human rights for profit: The system-preserving tendencies of the regional human rights courts. Capital \& Class, First published April 25, 2021. https://doi.org/10.1177/03098 168211005054.

Malm, A. (2016). Fossil Capital: The Rise of Steam Power and the Roots of Global Warming. London: Verso.

Michalowski, R.J. (1996). Critical criminology and the critique of domination: The story of an intellectual movement. Critical Criminology: An International Journal, 7(1), 9-16. https://doi.org/10.1007/BF02461091.

Moore, J. (2015). Capitalism in the Web of Life: Ecology and the Accumulation of Capital. London: Verso.

Samuels-Jones, T. (2021). David Whyte: Ecocide: Kill the Corporation Before It Kills Us. Critical Criminology: An International Journal, 29(4). https://doi.org/10.1007/s10612-021-09565-1..

White, R. (2021). David Whyte: Ecocide: Kill the Corporation Before It Kills Us. Critical Criminology: An International Journal, 29(4). https://doi.org/10.1007/s10612-021-09581-1.

Whyte, D. (2020). Ecocide: Kill the Corporation Before It Kills Us. Manchester, UK: Manchester University Press.

Whyte, D. (2021). Cop26: The day the net zero carnival came to town. The Independent, November 11. Retrieved on November 12, 2021, from https:/www.independent.co.uk/independentpremium/longreads/cop26-climate-change-conference-net-zero-carnival-b1954434.html.

Publisher's Note Springer Nature remains neutral with regard to jurisdictional claims in published maps and institutional affiliations. 